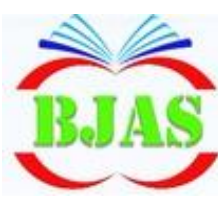

Available online at: http//bjas.bajas.edu.iq

College of Agriculture, University of Basrah

DOi:10.21276/basjas

ISSN 1814 - 5868 Basrah J. Agric. Sci., 32(Spec Issue): 70-79, 2019

\section{Basrah}

Journal of

Agricultural

Sciences

E-ISSN: 2520-0860

\title{
Effect of Substitution of Urea with Different Types and Levels of Ruminant Manure on Microbial Evaluation of Rice Straw Silage
}

\author{
Ali A. Saeed ${ }^{1 *}$ \& Saja I. Abid ${ }^{2}$ \\ ${ }^{1}$ Department of Animal Production, College of Agriculture, University of Al-Qasim Green, \\ ${ }^{2}$ Department of Animal Production, College of Agriculture, University of Wasit, Iraq \\ *Corresponding author e-mail: draliameensaeed59@agre.uoqasim.edu.iq
}

Received 15 March 2019; Accepted 8 June 2019; Available online 4 September 2019

\begin{abstract}
This study was conducted in Nutrition Lab. Department of Animal Production, College of Agriculture, Al-Qasim Green University to investigate the effect of type and level of substitution of urea with ruminant manure (sheep, cow and buffalo) on basis of nitrogen content on microbial composition of rice straw silage. Urea was substituted with dried manure at six combinations, 100:0, 90:10, 80:20, 70:30, 60:40 and 50:50. Silage samples were prepared by treating chopped straw with pre-treated solution contained $10 \%$ low quality juice and $2 \%$ urea. Treated straw was packed in double plastic bags which were closed tightly and fermented for 60 days in bits. Results revealed that samples prepared by addition of cow manure were characterized with higher number of total anaerobic $(\mathrm{P}<0.05)$ and lactic acid bacteria $(\mathrm{P}<0.01), 9.22$ and $8.62 \log$ CFU.g ${ }^{-1}$ FM respectively. Whereas, lower $(\mathrm{P}<0.01)$ number of molds and yeasts were detected in those prepared with addition of buffalo manure, 3.51 and 4.54 $\log$ CFU.g ${ }^{-1}$ FM respectively. Significant increases were also observed in the total number of anaerobic bacteria and lactic acid bacteria with lower $(\mathrm{P}<0.01)$ numbers of total aerobic bacteria due to substitution of urea with manure, however, lower $(\mathrm{P}<0.01)$ number of molds and yeasts, 3.49 and $4.51 \log \mathrm{CFU} \cdot \mathrm{g}^{-1} \mathrm{FM}$ were detected in samples prepared with a combination of 100:0 of urea: manure.
\end{abstract}

Keywords: Rice straw, Manure, Silage, Urea, Microbes.

\section{Introduction}

Nutritional requirements of ruminants are usually met through forages, characterized by low crude protein $(\mathrm{CP})$, low energy, high fiber, and poor digestibility (Borquez et al., 2009). The feeding value of poor quality fibrous feeds can be improved through various biological (ensiling), physical and chemical treatments (Sarwar et al., 2002). Ensiling is a preservation method where some bacteria break down cellulose and hemicellulose to simple sugars. Other bacteria ferment simple sugar to acidic end product under anaerobic conditions (Ogunjobi et al., 2010). The production of organic acids lead to decrease $\mathrm{pH}$ and the ensiled materials are preserved (Weinberg \& Muck, 1996). Thus, the main principles of preservation by ensiling are a rapid achievement of a low $\mathrm{pH}$ 
by lactic acid fermentation and the maintenance of anaerobic conditions. The low $\mathrm{pH}$ in combination with anaerobic condition and un dissociated acids prevents growth of undesirable bacteria, molds, and yeasts (Scudamore \& Livesey, 1998).

Silage microbes can basically be divided into two groups, namely the desirable and the undesirable. The desirable microbes are lactic acid bacteria. The undesirable ones are the organisms that can cause anaerobic spoilage (e.g., clostridia and enterobacteria) or aerobic spoilage e.g., yeasts, bacilli, listeria and molds (Ogunjobi et al., 2010).

Additives are commonly used in ensiling, among these additives, urea has gained great attention as it increases the CP contents of roughages. Molasses, being a rich source of readily available carbohydrate, accelerates microbial activities which may cause rapid drop in pH (Nisa et al., 2005).

Ruminant manure (M) is a valuable resource as a soil fertilizer providing nutrients required for the plant growth (Lazcano et al., 2008). Traditionally manure is normally spread in the farm without any treatment. When applied in excess to the land requirement can lead to environmental pollution (Nasiru et al., 2014).

To utilize manure as feedstuff different processing methods (dehydration, ensiling, pelleting, deep stacking and chemical preservation) have been employed (Borquez et al., 2009; Sarwar et al., 2011). Usage of manure as feedstuff in ruminant has the advantage of reducing pollution due to animal waste in addition to reducing feeding cost (Martinez-Avalos et al., 1998). However, some factors have affected efficient utilization of manure including palatability, ease of handling, product quality and consumer acceptance (Borquez et al., 2009). The method commonly used in treating manure as feed resource is fermentation with soluble nitrogen source such as urea and carbohydrate such as molasses through silage (Sarwar et al., 2006).

A manure silage was used to replace concentrates (Borquez et al., 2010). Up to $30 \%$ manure inclusion in silage making was recommended for optimal utilization in ruminant feeding (Nasiru et al., 2014).

Since ruminant manure is contaminated with many microbes, the current study aimed to investigate effect of ensiling urea-molasses treated rice straw (RS) on microbial community of fermented product.

\section{Materials \& Methods}

\section{Preparation of rice straw silage}

This study was conducted in the Nutrition laboratory, Department of Animal Production to evaluate the microbial composition of rice straw silages prepared by substitution of urea with ruminant manure (sheep, cow, or buffalo) at different ratios. Rice straw was obtained from newly harvested rice field of Al-Najaf Province. Chemical and microbial composition of RS are shown in tables ( 1 \& 2). Chemical composition was performed according to methods of AOAC (2004).

Samples of silage (control) were prepared by treating chopped rice straw $(1-2 \mathrm{~cm})$ with additives solution containing $10 \%$ of low quality date juice as a source of WSC and $2 \%$ of commercial urea as a source of nitrogen $(\mathrm{N})$. Manure was dried in the field to reduce moisture content partially, and in the laboratory using air draft oven at $105 \mathrm{C}^{\circ}$ for $24 \mathrm{hrs}$. to ensure the termination of microbial potential (Hall \& Keys, 1980). Urea was substituted with manure at 5 combinations of 
Table (1): Chemical composition of ensiled materials (\%) on dry matter basis.

\begin{tabular}{lcccccc}
\hline \multirow{2}{*}{ Nutrients } & \multirow{2}{*}{$\begin{array}{l}\text { Rice } \\
\text { straw }\end{array}$} & Urea & \multirow{2}{*}{$\begin{array}{c}\text { Date } \\
\text { juice }\end{array}$} & $\begin{array}{c}\text { Sheep } \\
\text { SM }\end{array}$ & $\begin{array}{c}\text { Cow } \\
\text { CM }\end{array}$ & $\begin{array}{c}\text { Buffalo } \\
\text { BM }\end{array}$ \\
\hline $\mathrm{DM}$ & 91.25 & - & 68.75 & 97.44 & 96.55 & 95.81 \\
\hline $\mathrm{Ash}$ & 19.75 & - & 2.57 & 12.74 & 21.01 & 24.14 \\
\hline $\mathrm{CP} *$ & 3.15 & $* 287.5$ & 2.20 & 7.81 & 4.35 & 4.14 \\
\hline $\mathrm{EE}$ & 4.53 & - & - & 3.26 & 3.37 & 3.46 \\
\hline $\mathrm{NDF}$ & 79.44 & - & - & 74.78 & 79.95 & 78.50 \\
\hline $\mathrm{ADF}$ & 51.02 & - & - & 41.61 & 40.33 & 39.87 \\
\hline $\mathrm{ADL}$ & 8.17 & - & - & 10.80 & 9.27 & 9.04 \\
\hline Cellulose & 42.85 & - & - & 30.81 & 31.06 & 30.83 \\
\hline Hemicellulose & 28.42 & - & - & 33.17 & 39.62 & 38.63 \\
\hline IVDMD $(\%)^{* *}$ & 39.32 & - & - & 48.64 & 49.62 & 46.11 \\
\hline IVOMD $(\%)^{* * *}$ & 41.20 & - & - & 55.61 & 49.91 & 48.14 \\
\hline
\end{tabular}

* 46×6.25 **IVDMD: in vitro dry matter digestibility and ***IVOMD: in vitro organic matter digestibility, were performed according to method described by Tilley \& Terry (1963)

Table (2): Microbial composition of straw and manure (log CFU.g ${ }^{-1}$ DM).

\begin{tabular}{|c|c|c|c|c|}
\hline \multirow[b]{2}{*}{ Microbes } & \multirow{2}{*}{$\begin{array}{l}\text { Rice } \\
\text { straw }\end{array}$} & \multicolumn{3}{|c|}{ Manure } \\
\hline & & $\begin{array}{c}\text { Sheep, } \\
\text { SM }\end{array}$ & $\begin{array}{c}\text { Cow, } \\
\text { CM }\end{array}$ & $\begin{array}{c}\text { Buffalo, } \\
\text { BM }\end{array}$ \\
\hline $\begin{array}{l}\text { Aerobic } \\
\text { bacteria }\end{array}$ & 6.3 & 5.6 & 5.84 & 5.47 \\
\hline $\begin{array}{l}\text { Anaerobic } \\
\text { bacteria }\end{array}$ & 9.3 & 8.9 & 8.84 & 8.95 \\
\hline Molds & 4 & $\underline{3.47}$ & $\underline{3.47}$ & $\underline{3.69}$ \\
\hline Yeasts & $\underline{4.69}$ & $\underline{4.47}$ & $\underline{4.47}$ & $\underline{4.69}$ \\
\hline LAB & 8.47 & 8.47 & 8.47 & 8.47 \\
\hline
\end{tabular}

urea: manure, 90:10, 80:20, 70:30, 60:40 and 50:50. In control silage this combination was 100:0. All additives (urea, date juice, manure) were used on basis of dry matter (DM). Additives mix were diluted with quantity of water to ensure DM content of ensiled materials of about $40 \%$. Additives solutions were sprayed on chopped RS with continuous mixing to distribute the solution to all parts of straw. Treated straw samples were then packed in double nylon bags to avoid deterioration of silage due to entering of air through probable punctures or cuts. Contents inside bags were squeezed by hands to exclude air may penetrated straw mass, closed tightly and stored in a bit silo for 60 days.
Rice straw silage (RSS) prepared with sheep (SM), cow (CM) or buffalo manure (BM) will be symbolized as RSS-SM, RSS-CM and RSS-BM respectively.

\section{Microbial analysis}

Microbial analysis of silages including total count of aerobic, anaerobic and lactic acid bacteria, yeasts and molds were performed in duplicate shortly after each bags were opened. one $g$ was taken from each silage samples and blended with $9 \mathrm{ml}$ of sterilized peptone water (Wu et al., 2014). The suspensions produced were serially diluted $\left(10^{-1}\right.$ to $\left.10^{-10}\right)$ in peptone water as described by Harrigan \& McCane (1976). $100-\mu \mathrm{L}$ aliquots of each dilution was spread onto selective medias as follows:

Aerobic bacteria were counted on nutrient agar and autoclaved at $37^{\circ} \mathrm{C}$ for $24 \mathrm{hr}$ (Sood, 1987). Plates were incubated in an incubator at $37^{\circ} \mathrm{C}$ for $24-48 \mathrm{hr}$. The same steps were performed to count anaerobic bacteria but plates were incubated anaerobically at $37^{\circ} \mathrm{C}$ for 24-48 hrs. (Adesoji et al., 2010). Lactic acid bacteria (LAB) were counted on deMan, Rogosa, and Sharpe agar after incubation at $37^{\circ} \mathrm{C}$ for $48 \mathrm{hrs}$. under anaerobic conditions 
(Addah et al., 2014). Yeasts were counted on malt extract agar. Plates were incubated aerobically at $25^{\circ} \mathrm{C}$ for $72 \mathrm{~h}$ (Akintokun et al., 2014). Molds were counted on potato dextrose. Plates were incubated aerobically at $25^{\circ} \mathrm{C}$ for $72 \mathrm{hrs}$. (Adesoji et al., 2010).

Colonies were counted as viable numbers of microorganisms from plates containing a minimum of 30 and a maximum of 300 colonies. All analysis was carried out using the aseptic technique by using sterilized equipment and solutions to prevent contamination. Numbers of microbes are expressed as colony-forming units (CFU) per $\mathrm{g}$ of fresh silages (FM) and were $\log$ transformed.

\section{Statistical analysis}

Data obtained were analyzed as a factorial experiment in completely randomized design by analysis of variance using Statistical Analysis System, (SAS, 2010).

\section{Results \& Discussion}

Microbial evaluation of rice straw silage included enumeration of total aerobic and anaerobic bacteria, molds, yeasts and lactic acid bacteria (LAB) according to critical role of these organisms in silage fermentation. Table (3) indicated numbers of microbial populations (log CFU.g ${ }^{-1}$ fresh matter, FM) in reed silages as affected by addition of types of ruminant manure and urea: manure combinations.

As shown numbers of all microbes tested were significantly affected by types of manure. Statistical analysis revealed that there was a significant $(\mathrm{P}<0.05)$ increase in numbers of total aerobic bacteria in samples of RSS-SM as compared with RSS-CM and RSS-BM, (0.13 and 0.14 log CFU.g ${ }^{-1}$ FM respectively). This increase may be caused by nature of SM and the way that silage samples were prepared particularly, in relation with squeezing nylon bags to exclude air. Saeed et al. (2017) and Levital et al. (2009) considered anaerobic condition as a principal to ensure desired fermentation and producing good quality silage.

Regarding effect of urea: manure combinations, results showed that there was a significant $(\mathrm{P}<0.01)$ decrease in numbers of total aerobic bacteria in RSS samples prepared with each substitution of urea with manure. Numbers of this bacteria were 6.23 , 5.95, 5.73, 5.76, 5.78 and $5.81 \log$ CFU.g ${ }^{-1}$ FM for urea: manure combinations of 100:0, $90: 10, \quad 80: 20, \quad 70: 30, \quad 60: 40$ and 50:50 respectively. This decrease may be due to the better condition available to other silage microbes especially LAB, such a decrease in $\mathrm{pH}$ resulted from lowering urea level associated with introducing manure in theses combinations. Urea is characterized with rapid degradation during ensiling (Sarwar et al., 2006; Saeed et al., 2017; Khan et al., 2006). Moreover, increasing manure level in combinations may provide microbes with additional energy. Abid (2018) reported that substitution urea with ruminant manure not only decreased silage $\mathrm{pH}$, but decreased ammonia nitrogen $\left(\mathrm{NH}_{3}-\mathrm{N}\right)$ and increased concentration of volatile fatty acids too.

Results exhibited that number of total anaerobic bacteria was increased $(\mathrm{P}<0.05)$ in samples of RSS-CM by 0.11 and $0.04 \mathrm{log}$ CFU.g ${ }^{-1}$ FM as compared with RSS-SM and RSS-BM respectively. This may be due to the improvement of ensiling conditions of RSSCM samples thereby it was reflected on silage fermentation. Such positive changes in ensiling conditions were confirmed by Abid (2018).

Regarding the effect of urea: manure combinations, results revealed that there was a significant $(\mathrm{P}<0.01)$ increase in number of 
Saeed \& Abid / Basrah J. Agric. Sci., 32 (Special Issue): 70-79, 2019

Table (3): Effect of type of ruminant manure and urea: manure combinations (\%) on numbers of microbes in rice straw silage $\left(\log \mathrm{CFU}^{*} \cdot \mathrm{g}^{-1} \mathrm{FM} \pm \mathrm{SE}\right)$.

\begin{tabular}{|c|c|c|c|c|c|c|c|c|c|c|c|}
\hline \multirow{2}{*}{ Microorganisms } & \multicolumn{3}{|c|}{ Type of manure, TM } & \multicolumn{6}{|c|}{ Urea: manure combinations (\%), Com. } & \multicolumn{2}{|c|}{$P$-value } \\
\hline & SM & $\mathrm{CM}$ & $\mathrm{BM}$ & 100:0 & 90:10 & $80: 20$ & $70: 30$ & $60: 40$ & $50: 50$ & TM & Com. \\
\hline Total aerobic bacteria & $\begin{array}{c}5.97^{\mathrm{a}} \\
\pm 0.04\end{array}$ & $\begin{array}{l}5.84^{b} \\
\pm 0.05\end{array}$ & $\begin{array}{c}5.83^{b} \\
\pm 0.05\end{array}$ & $\begin{array}{l}6.23^{\mathrm{a}} \\
\pm 0.07\end{array}$ & $\begin{array}{c}5.95^{b} \\
\pm 0.03\end{array}$ & $\begin{array}{c}5.73^{c} \\
\pm 0.05\end{array}$ & $\begin{array}{l}5.76^{\mathrm{c}} \\
\pm 0.05\end{array}$ & $\begin{array}{c}5.78^{c} \\
\pm 0.08\end{array}$ & $\begin{array}{l}5.81^{b c} \\
\pm 0.06\end{array}$ & $*$ & $* *$ \\
\hline Total anaerobic bacteria & $\begin{array}{r}9.11^{\mathrm{b}} \\
\pm 0.03 \\
\end{array}$ & $\begin{array}{r}9.22^{\mathrm{a}} \\
\pm 0.03\end{array}$ & $\begin{array}{c}9.18^{b} \\
\pm 0.03\end{array}$ & $\begin{array}{c}8.95^{\mathrm{b}} \\
\pm 0.07\end{array}$ & $\begin{array}{c}9.18^{\mathrm{a}} \\
\pm 0.04\end{array}$ & $\begin{array}{c}9.24^{\mathrm{a}} \\
\pm 0.03\end{array}$ & $\begin{array}{c}9.23^{\mathrm{a}} \\
\pm 0.03\end{array}$ & $\begin{array}{r}9.20^{\mathrm{a}} \\
\pm 0.03\end{array}$ & $\begin{array}{c}9.22^{\mathrm{a}} \\
\pm 0.03\end{array}$ & $*$ & $* *$ \\
\hline Molds & $\begin{array}{c}3.76^{\mathrm{a}} \\
\pm 0.05\end{array}$ & $\begin{array}{c}3.62^{b} \\
\pm 0.03\end{array}$ & $\begin{array}{c}3.51^{\mathrm{c}} \\
\pm 0.01\end{array}$ & $\begin{array}{c}3.49^{d} \\
\pm 0.03\end{array}$ & $\begin{array}{l}3.56^{\mathrm{cd}} \\
\pm 0.04\end{array}$ & $\begin{array}{l}3.61^{b c} \\
\pm 0.06\end{array}$ & $\begin{array}{l}3.68^{\mathrm{ab}} \\
\pm 0.07\end{array}$ & $\begin{array}{l}3.66^{\mathrm{bc}} \\
\pm 0.05\end{array}$ & $\begin{array}{c}3.77^{\mathrm{a}} \\
\pm 0.08\end{array}$ & $* *$ & $* *$ \\
\hline Yeasts & $\begin{array}{r}4.60^{\mathrm{a}} \\
\pm 0.02\end{array}$ & $\begin{array}{r}4.64^{\mathrm{a}} \\
\pm 0.03\end{array}$ & $\begin{array}{r}4.54^{\mathrm{b}} \\
\pm 0.01\end{array}$ & $\begin{array}{l}4.51^{\mathrm{b}} \\
\pm 0.02\end{array}$ & $\begin{array}{r}4.51^{b} \\
\pm 0.02\end{array}$ & $\begin{array}{r}4.54^{b} \\
\pm 0.03\end{array}$ & $\begin{array}{r}4.64^{\mathrm{a}} \\
\pm 0.02\end{array}$ & $\begin{array}{r}4.66^{\mathrm{a}} \\
\pm 0.06\end{array}$ & $\begin{array}{r}4.71^{\mathrm{a}} \\
\pm 0.01\end{array}$ & $* *$ & $* *$ \\
\hline LAB & $\begin{array}{l}8.60^{\mathrm{a}} \\
\pm 0.03\end{array}$ & $\begin{array}{c}8.62^{\mathrm{a}} \\
\pm 0.04\end{array}$ & $\begin{array}{c}8.47^{b} \\
\pm 0.01\end{array}$ & $\begin{array}{c}8.32^{c} \\
\pm 0.00\end{array}$ & $\begin{array}{c}8.53^{b} \\
\pm 0.03\end{array}$ & $\begin{array}{l}8.54^{\mathrm{b}} \\
\pm 0.02\end{array}$ & $\begin{array}{c}8.64^{\mathrm{a}} \\
\pm 0.05\end{array}$ & $\begin{array}{c}8.68^{a} \\
\pm 0.07\end{array}$ & $\begin{array}{c}8.66^{\mathrm{a}} \\
\pm 0.03\end{array}$ & $* *$ & $* *$ \\
\hline
\end{tabular}

* $\log$ colony forming unit/g FM

Means with different letters within each row are significantly differed at *

$(\mathbf{P}<\mathbf{0 . 0 5}), * *(\mathbf{P}<\mathbf{0 . 0 1}$ 
total anaerobic bacteria in RSS samples prepared with inclusion of manure as compared with a urea: manure combination of 100:0. Numbers of these bacteria were, 9.18, 9.24, 9.23, 9.20 and 9.22 $\log$ CFU.g ${ }^{-1}$ FM for $90: 10, \quad 80: 20, \quad 70: 30, \quad 60: 40$ and 50:50 combinations of urea: manure respectively. This can be explained on the basis of basic conditions associated with RSS samples prepared with urea only which may discourages growth of anaerobic microbes. Molds number of RSS-SM increased $(\mathrm{P}<0.01)$ as compared with RSS-CM and RSS-BM, (3.76, 3.62 and $3.51 \log$ CFU.g ${ }^{-1}$ FM respectively).

Results also revealed that there was a decrease $(\mathrm{P}<0.01)$ in molds numbers in RSS samples prepared with urea: Manure combination of 100:0 as compared with other combinations. This decrease may be attributed to the antifungal role of ammonia released from degradation of urea during ensiling (Kung et al., 2000). This role seemed to be minimized with increasing level of urea in the urea: manure combinations used in preparing RSS in a current study. While molds were negatively affected by antifungal role of urea, it was significantly increased $(\mathrm{P}<0.01)$ as manure was introduced in combination of urea: manure due to lower $\mathrm{NH}_{3}-\mathrm{N}$ concentration (Abid, 2018).

Regarding yeasts, lower number $(\mathrm{P}<0.01)$ was detected in RSS-BM as compared with RSS-SM and RSS-CM, numbers of yeasts were $4.54,4.60$ and $4.64 \log \mathrm{CFU}_{\mathrm{g}^{-1}} \mathrm{FM}$ respectively. Results of the current study indicated that yeasts number were also decreased $(\mathrm{P}<0.01)$ in RSS prepared with urea: manure combinations of 100:0, 90:10 and 80:20, numbers were, 4.51, 4.51 and 4.54 as compared with 4.64, 4.66 and $4.71 \log$ CFU.g ${ }^{-1}$ FM in RSS prepared with urea: manure combinations of $70: 30,60: 40$ and 50:50 respectively. These results can also be explained on basis of antifungal role of ammonia (Kung et al., 2000).

Numbers of lactic acid bacteria (LAB) were increased $(\mathrm{P}<0.01)$ in $\mathrm{RSS}-\mathrm{CM}$ and RSS-SM as compared with RSS-BM, numbers were, 8.62, 8.60 and 8.47 log CFU.g1 FM respectively. Numbers of LAB were also affected by urea: manure combinations. Higher numbers $(\mathrm{P}<0.01)$ were detected in RSS prepared with combinations of 70:30, 60:40 and 50:50 as compared with other combinations. Numbers of LAB were, 8.64, 8.68 and 8.66 respectively, vs. 8.32, 8.53 and $8.53 \log$ CFU.g ${ }^{-1}$ FM for combinations of 100:0, 90:10 and 80:20 respectively. This result indicated that there was an increase in LAB numbers with increasing level of manure in those urea: Manure combinations. This increase may be due to availability of additional substrates particularly water soluble carbohydrates (WSC). Kuikui et al. (2014) referred to the importance of such nutrients (substrates) to maintain growth and activity of complex group of microbes particularly LAB which converts WSC to lactic acid (LA) and reduced $\mathrm{pH}$ accordingly.

Numbers of LAB can also be affected by nature of dominant LA fermentation, in homofermentative LAB lower WSC was consumed in comparison with heterofermentative (Weinberg \& Muck, 1996), leading to more substrate available for LAB which may reflected positively on its numbers in silage.

Table (4) explained the effect of the interaction between type of manure and urea: manure combinations on numbers of microbes included in microbial evaluation of a current study. Statistical analysis showed that all microbes were affected $(\mathrm{P}<0.01)$ by that 
Saeed \& Abid / Basrah J. Agric. Sci., 32 (Special Issue): 70-79, 2019

Table (4). Effect of interaction between type of manure and urea: manure combinations on numbers of microbes in rice straw silage

\begin{tabular}{|c|c|c|c|c|c|c|c|c|c|c|c|c|c|c|c|c|c|}
\hline & & & & & & & \multicolumn{10}{|c|}{$\left(\log C F U . g^{-1} \quad F M \pm S E\right)$} & \\
\hline \multirow{3}{*}{ Microbes } & \multirow{3}{*}{$\begin{array}{c}100 \% \\
\text { urea }\end{array}$} & \multirow{2}{*}{\multicolumn{5}{|c|}{$\begin{array}{c}\text { Sheep manure } \\
\text { Combinations of urea: manure }\end{array}$}} & \multirow{2}{*}{\multicolumn{5}{|c|}{$\begin{array}{r}\text { Cow manure } \\
\text { Combinations of urea: }\end{array}$}} & \multicolumn{5}{|c|}{ Buffalo manure } & \multirow{3}{*}{$\begin{array}{c}P- \\
\text { value }\end{array}$} \\
\hline & & & & & & & & & & & & & Combinat & ons of ur & manur & & \\
\hline & & $90: 10$ & $\underline{80: 20}$ & 70:30 & 60:40 & $\underline{50: 50}$ & $90: 10$ & $\underline{80: 20}$ & 70:30 & $-60: 40$ & 50:50 & $90: 10$ & $\underline{80: 20}$ & 70:30 & $\underline{60: 40}$ & $\underline{50: 5}$ & \\
\hline $\begin{array}{l}\text { Total aerobic } \\
\text { bacteria }\end{array}$ & $\begin{array}{l}6.30^{\mathrm{a}} \\
\pm 0.02\end{array}$ & $\begin{array}{l}5.90^{\mathrm{bcdef}} \\
\pm 0.04\end{array}$ & $\begin{array}{l}5.89^{\text {bcdef }} \\
\pm 0.07\end{array}$ & $\begin{array}{l}5.94 \text { bcde } \\
\pm 0.06\end{array}$ & $\begin{array}{l}5.72^{\mathrm{defg}} \\
\pm 0.09\end{array}$ & $\begin{array}{l}6.05^{\mathrm{abc}} \\
\pm 0.06\end{array}$ & $\begin{array}{l}5.96^{\text {bcde }} \\
\pm 0.06\end{array}$ & $\begin{array}{l}5.49^{\mathrm{g}} \\
\pm 0.02\end{array}$ & $\begin{array}{l}5.73^{\mathrm{defg}} \\
\pm 0.09\end{array}$ & $\begin{array}{l}5.98^{\mathrm{bcd}} \\
\pm 0.02\end{array}$ & $\begin{array}{l}5.75^{\mathrm{cdefg}} \\
\pm 0.02\end{array}$ & $\begin{array}{l}5.99^{\mathrm{bcd}} \\
\pm 0.06\end{array}$ & $\begin{array}{l}5.80^{\mathrm{bcdef}} \\
\pm 0.04\end{array}$ & $\begin{array}{l}5.60^{\mathrm{fg}} \\
\pm 0.05\end{array}$ & $\begin{array}{l}5.66^{\mathrm{efg}} \\
\pm 0.19\end{array}$ & $\begin{array}{l}5.63^{\mathrm{fg}} \\
\pm 0.07\end{array}$ & $* *$ \\
\hline $\begin{array}{l}\text { Total anaerobic } \\
\text { bacteria }\end{array}$ & $\begin{array}{c}8.95^{\mathrm{b}} \\
\pm 0.13\end{array}$ & $\begin{array}{l}8.96^{\mathrm{b}} \\
\pm 0.02\end{array}$ & $\begin{array}{l}9.18^{\mathrm{ab}} \\
\pm 0.07\end{array}$ & $\begin{array}{l}9.16^{\mathrm{ab}} \\
\pm 0.08\end{array}$ & $\begin{array}{l}9.18^{\mathrm{ab}} \\
\pm 0.07\end{array}$ & $\begin{array}{l}9.24^{\mathrm{a}} \\
\pm 0.06\end{array}$ & $\begin{array}{r}9.30^{\mathrm{a}} \\
\pm 0.00\end{array}$ & $\begin{array}{l}9.24^{\mathrm{a}} \\
\pm 0.06\end{array}$ & $\begin{array}{l}9.30^{\mathrm{a}} \\
\pm 0.00\end{array}$ & $\begin{array}{l}9.30^{\mathrm{a}} \\
\pm 0.00\end{array}$ & $\begin{array}{l}9.24^{\mathrm{a}} \\
\pm 0.06\end{array}$ & $\begin{array}{l}9.30^{\mathrm{a}} \\
\pm 0.06\end{array}$ & $\begin{array}{r}9.30^{\mathrm{a}} \\
\pm 0.00\end{array}$ & $\begin{array}{r}9.24^{\mathrm{a}} \\
\pm 0.06\end{array}$ & $\begin{array}{l}9.12^{\mathrm{ab}} \\
\pm 0.07\end{array}$ & $\begin{array}{l}9.18^{\mathrm{ab}} \\
\pm 0.07\end{array}$ & $*$ \\
\hline Molds & $\begin{array}{l}3.49^{\mathrm{d}} \\
\pm 0.06\end{array}$ & $\begin{array}{c}3.47^{\mathrm{d}} \\
\pm 0.00\end{array}$ & $\begin{array}{l}3.91^{\mathrm{b}} \\
\pm 0.08\end{array}$ & $\begin{array}{l}3.92^{\mathrm{b}} \\
\pm 0.13\end{array}$ & $\begin{array}{l}3.56^{\mathrm{cd}} \\
\pm 0.05\end{array}$ & $\begin{array}{c}4.20^{\mathrm{a}} \\
\pm 0.06\end{array}$ & $\begin{array}{l}3.72^{\mathrm{c}} \\
\pm 0.08\end{array}$ & $\begin{array}{l}3.47^{\mathrm{d}} \\
\pm 0.00\end{array}$ & $\begin{array}{l}3.63^{\mathrm{cd}} \\
\pm 0.09\end{array}$ & $\begin{array}{l}3.93^{\mathrm{d}} \\
\pm 0.06\end{array}$ & $\begin{array}{l}3.47^{\mathrm{d}} \\
\pm 0.00\end{array}$ & $\begin{array}{l}3.49^{\mathrm{d}} \\
\pm 0.02\end{array}$ & $\begin{array}{l}3.47^{\mathrm{d}} \\
\pm 0.00\end{array}$ & $\begin{array}{l}3.51^{\mathrm{d}} \\
\pm 0.04\end{array}$ & $\begin{array}{l}3.48^{\mathrm{d}} \\
\pm 0.01\end{array}$ & $\begin{array}{l}3.63^{\mathrm{cd}} \\
\pm 0.04\end{array}$ & $* *$ \\
\hline Yeast & $\begin{array}{l}4.51^{\mathrm{cd}} \\
\pm 0.04\end{array}$ & $\begin{array}{l}4.47^{\mathrm{d}} \\
\pm 0.00\end{array}$ & $\begin{array}{l}4.70^{\mathrm{b}} \\
\pm 0.07\end{array}$ & $\begin{array}{l}4.71^{\mathrm{b}} \\
\pm 0.07\end{array}$ & $\begin{array}{l}4.54^{\mathrm{cd}} \\
\pm 0.04\end{array}$ & $\begin{array}{l}4.70^{\mathrm{b}} \\
\pm 0.01\end{array}$ & $\begin{array}{l}4.54^{\mathrm{cd}} \\
\pm 0.04\end{array}$ & $\begin{array}{l}4.47^{\mathrm{d}} \\
\pm 0.00\end{array}$ & $\begin{array}{l}4.61^{\mathrm{bc}} \\
\pm 0.01\end{array}$ & $\begin{array}{l}4.98^{\mathrm{a}} \\
\pm 0.08\end{array}$ & $\begin{array}{l}4.73^{\mathrm{b}} \\
\pm 0.04\end{array}$ & $\begin{array}{l}4.54^{\mathrm{cd}} \\
\pm 0.04\end{array}$ & $\begin{array}{l}4.47^{\mathrm{d}} \\
\pm 0.00\end{array}$ & $\begin{array}{l}4.60^{\mathrm{bcd}} \\
\pm 0.00\end{array}$ & $\begin{array}{l}4.47^{\mathrm{d}} \\
\pm 0.00\end{array}$ & $\begin{array}{c}4.70^{\mathrm{b}} \\
0.01 \pm\end{array}$ & $* *$ \\
\hline LAB & $\begin{array}{l}8.32^{\mathrm{d}} \\
\pm 0.01\end{array}$ & $\begin{array}{l}8.54^{\mathrm{c}} \\
\pm 0.04\end{array}$ & $\begin{array}{l}8.64^{\mathrm{bc}} \\
\pm 0.05\end{array}$ & $\begin{array}{l}8.77^{\mathrm{b}} \\
\pm 0.10\end{array}$ & $\begin{array}{l}8.55^{\mathrm{c}} \\
\pm 0.05\end{array}$ & $\begin{array}{l}8.79^{b} \\
\pm 0.06\end{array}$ & $\begin{array}{l}8.60^{c} \\
\pm 0.08\end{array}$ & $\begin{array}{l}8.50^{\mathrm{c}} \\
\pm 0.03\end{array}$ & $\begin{array}{l}8.64^{\mathrm{bc}} \\
\pm 0.09\end{array}$ & $\begin{array}{l}9.04^{\mathrm{a}} \\
\pm 0.06\end{array}$ & $\begin{array}{l}8.60^{\mathrm{c}} \\
\pm 0.02\end{array}$ & $\begin{array}{l}8.47^{\mathrm{cd}} \\
\pm 0.00\end{array}$ & $\begin{array}{l}8.47^{\mathrm{cd}} \\
\pm 0.00\end{array}$ & $\begin{array}{r}8.51^{\mathrm{c}} \\
0.04 \pm\end{array}$ & $\begin{array}{l}8.47^{\mathrm{cd}} \\
\pm 0.00\end{array}$ & $\begin{array}{l}8.58^{\mathrm{c}} \\
\pm 0.04\end{array}$ & $* *$ \\
\hline
\end{tabular}

* log colony forming unit/g FM

Means with different letters within each row are significantly differed at * $(\mathbf{P}<0.05), * *(P<0.01)$. 
interaction. Higher numbers $(\mathrm{P}<0.01)$ of total aerobic bacteria (6.30) were detected in samples of RSS prepared with urea: manure combination of 100:0 (No manure), whereas, lower numbers (5.49 log CFU.g ${ }^{-1}$ FM) were associated with RSS-CM samples prepared with urea: manure combination of 80:20. This result can be explained on the basis of availability of suitable medium for other microbes particularly LAB such as low $\mathrm{pH}$ resulted from reduced level of urea characterized with rapid degradation during ensiling (Khan et al., 2006; Sarwar et al., 2006; Saeed et al., 2017). Consistently, higher numbers $(\mathrm{P}<0.01)$ of total anaerobic bacteria including $\mathrm{LAB}$ were detected in all RSS samples prepared with addition of manure regardless to its type (SM, CM or BM).

Results of interaction effect also explained that higher numbers $(\mathrm{P}<0.01)$ of molds were detected in RSS-SM samples prepared with urea: Manure combination of 50: 50 (4.20) as compared with lower numbers detected in RSS-SM samples prepared with a combination of 90: 10 (3.47), RSS-CM prepared with a combination of 80:20 (3.47) and 50:50 (3.47) and RSS-BM prepared with a combination of 80:20 (3.47 log CFU.g ${ }^{-1}$ FM). This may due to antifungal effect of ammonia (Kung et al., 2000) produced during ensiling from rapid degradation of urea (Catchpoole, 1970).

Higher numbers $(\mathrm{P}<0.01)$ of yeast (4.98) was observed in RSS-CM samples prepared with urea: Manure combination of 60:40 as compared with $4.47 \log$ CFU.g ${ }^{-1}$ FM detected in RSS-SM prepared with a combination of 90:10, RSS-CM prepared with a combination of 80:20 and RSS-BM prepared with combinations of 80:20 and 60:40. This result may attributed to the role of ammonia accumulated during ensiling.
Numbers of LAB were higher $(\mathrm{P}<0.01)$ in RSS-CM samples prepared with urea: manure combination of 60:40 (9.04) as compared with other samples. Whereas, lower numbers were detected in RSS prepared without addition of manure (combination 100:0) and in RSS-BM samples prepared with combinations of 90:10, 80:20 and 60:40, numbers of LAB in these RSS were 8.32, 8.47, 8.47 and $8.47 \mathrm{log}$ CFU.g ${ }^{-1}$ FM respectively. The priority of RSS-CM prepared with a combination of 60:40 may be associated with better condition for LAB growth. McDonald et al. (1991) reported that acidic medium in the initial phases of ensiling is a cornerstone for the subsequent dominance of LAB on silage fermentation. Abid (2018) attributed higher LAB numbers in RSS-CM to a decrease in $\mathrm{pH}$.

\section{Conclusions}

The results suggest that the substitution of urea with ruminant manure at different levels had clear effects on microbial counts of rice straw silages. Changes in numbers of total aerobic, anaerobic bacteria and LAB referred to an improvement in silage quality. Anaerobic condition associated with preparing silage samples may have a significant influence on silage fermentation. Additional efforts should be done to overcome the increase in numbers of undesired microbes such as molds and yeasts.

\section{Acknowledgements}

The authors wish to express their appreciation to Miss Rabab J. Hassan a technician of the Microbiology lab., College of Food Science, University of Al-Qasim Green for her valuable and unlimited assistance.

Conflict of interest: The authors declare that they have no conflict of interest. 


\section{References}

Abid, S.I. (2018). Effect of substitution of urea with different ratios of ruminant manure to improve nutritive value of rice straw silage. M. Sc. Thesis. Univ. AlQasim Green: 105pp.

Addah, W.; Baaha, J.E.; Okineb, K.; Owensd, F.N. \& McAllistera, T.A. (2014). Effects of chop-length and a ferulic acid esteraseproducing inoculant on fermentation and aerobic stability of barley silage, and growth performance of finishing feedlot steers. Anim. Feed Sci. Tech., 197: 34-46.

Adesoji, A.T.; Ogunjobi, A.A.; Fagade, O.E. \& Babayemi, O.J. (2010). Effect of Lactobacillus plantarum starter culture on the microbial succession, chemical composition, aerobic stability and acceptability by ruminant of fermented Panicum maximum grass. Asian-Aust. J.T., 14(1): 11-24.

Akintokun, A.; Jolaosho A.O. \& Afolabi, R.O. (2014). Effect of L. Plantarum and carbohydrase on microbes and composition of T. Procumbens silage. Arch. Zootec., 56: 145-156.

AOAC, (2004). Official Methods for Analysis of Association officials of analysis chemists. $11^{\text {th }}$ ed. Washington. D.C.: 375pp.

Borquez J.L.; Gonzalez-Munoz, S.S.; PinosRodriguez, J.M.; Domınguez, I.; Barcena, J.R.; Mendoza, G.D.; Cobos, M.A. Bueno, G. (2009). Feeding value of ensiling fresh cattle manure with molasses or bakery byproducts in lambs. Livestock Sci., 122(2-3): 276-280.

Borquez, J.L.; Pinos-Rodríguez, J.M.; González, S.S.; Domínguez, I.; Bárcena, R. Mendoza, G. \& Cobos, M. (2010). Use of different kind of silage dairy cattle manure in lamb nutrition. Italian J. Anim. Sci., 9(25): 129-133.

Catchpoole, V.R. (1970). The silage fermentation of some tropical pasture plants. Proc. $11^{\text {th }}$ Int. Grass. Congr., Queensland, Australia, Univ. Queensland Press, St. Lucia: 956pp.

Hall, D.G. \& Keys, M.J. (1980). Evaluation of poultry manure as a nitrogen supplement to diets of oats and roughages for sheep. Aust. J. Exp. Agric. Anim. Husb., 20(105): 427-432.

Harrigan, W.F. \& McCane, M.E. (1976). Laboratory Methods in Food and Microbiology. $1^{\text {st }}$ ed. Academic Press, London: 452pp.

Khan, M.A.; Iqbal, Z.; Sarwar, M.; Nisa, M.; Khan, M.S.; Lee, H.J.; Lee, W.S.; Kim, H.S. \& Ki, K.S. (2006). Urea treated corncobs ensiled with or without additives for buffaloes: Ruminal characteristics, digestibility and nitrogen metabolism. Asian-Aust. J. Anim. Sci., 19(5): 705-712.

Kung, J.L.; Robinson, J.R. \& Pesek, J.D. (2000). Microbial populations, fermentation end products and aerobic stability of corn silage treated with ammonia or a propionic acid based preservative. J. Dairy. Sci., 83: 1479-1486.

Lazcano C.; Gomez-Brandon, M. \& Dominguez, J. (2008). Comparison of the effectiveness of composting and vermincomposting for the biological stabilization of cattle manure. Chemosphere, 72(7): 1013-1019.

Levital, T.; Mustafaa, A.F.; Seguinb, P. \& Lefebvrec, G. (2009). Effects of a propionic acid-based additive on shortterm ensiling characteristics of whole plant maize and on dairy cow performance. Anim. Feed Sci. Tech., 152: 21-32. 
Martınez-Avalos, A.M.M.; Mendoza, G.D.; Cobos, M.A.; Gonzalez, S.; Garcia-Bojalil, C.M. \& Barcena, R. (1998). Nutritional evaluation of cattle manure silage with molasses for ruminants. Anim. Feed Sci. Technol., 70(3): 257-264.

McDonald, P.; Hunderson, A.R. \& Heron, S.J.E. (1991). The Biochemistry of Silage, $2^{\text {nd }}$ ed. Cambrian Printers Lt. Aberystwyth: 340pp.

Nasiru, A.; Ibrahim, M.H. \& Ismail, N. (2014). Nitrogen losses in ruminant manure management and use of cattle manure vermicast to improve forage quality. Int. J. Recy. Org. Waste Agric. 3(57): 1-7.

Ni, K.; Wang, Y.; Pang, H. \& Cai, Y. (2014). Effect of cellulase and lactic acid bacteria on fermentation quality and chemical composition of wheat straw silage. Am. J. Plant Sci., 5(13): 1877-1884.

Nisa, M.; Touqir, N.A.; Sarwar, M.; Ajmal Khan, M. \& Akhtar, M. (2005). Effect of additives and fermentation periods on chemical composition and In situ digestion kinetics of Mott grass (Pennisetum purpureum) Silage. Asian-Aust. J. Anim. Sci., 18(6): 812- 815

Ogunjobi, A.A.; Ibekwe, A.C.; Babayemi, O.J. \& Fagade, O.E. (2010). Microbiological evaluation of ensiled guinea grass and albizia saman pod mixtures and its effect on rumen bacterial population using in vitro fermentation technique. Asian-Aust. J.T., 13(4): 223232.

Saeed, A.A.; AlSultani, H.M.H. \& Mottaleb, A.S. (2017). Effect of addition of different levels of baker's yeast Saccharomyces cerevisiae on fermentation quality and nutritive value of ensiled whole yellow corn crop residuals. Euphrates J. Agric. Sci., 9(1): 8-18.

Sarwar, M.; Khan, M.A. \& Iqbal, Z. (2002). Feed resources for livestock in Pakistan. Int. J. Agric. Biol., 4: 186-192.

Sarwar, M.; Nisa, M.; Hassan, Z. \& Shahzad, M.A. (2006). Influence of urea molasses treated wheat straw fermented with cattle manure on chemical composition and feeding value for growing buffalo calves. Livestock Sci., 105: 151-161.

Sarwar, M.; Shahzad, M.; Nisa, M.; Afzal, D.; Sharif, M. \& Saddiqi, H. (2011) Feeding value of urea molasses-treated wheat straw ensiled with fresh cattle manure for growing crossbred cattle calves. Trop. Anim. Health Prod., 43(3): 543-548.

SAS (2010). SAS/STAT User's Guide for Personal Computers. Release6.12.SAS. Institute Inc., Cary, NC, USA.

Scudamore, K.A. \& Livesey, C.T. (1998). Occurrence and significance of mycotoxins in forage corps and silage: A review. J. Sci. Food and Agric., 77(1): 1-17.

Sood, R. (1987). Medical Laboratory Technology (Methods and Interpretations). Jaypee Brothers. Medical Publishers. $2^{\text {nd }}$ Ed., Emca House. 1033pp.

Tilley, J.M. \& Terry, R.A. (1963). A two stage technique for in vitro digestion of forage crops. J. Br. Grassland Sci., 18(2): 104-111.

Weinberg, Z.G. \& Muck, R.E. (1996). New trends and opportunities in the development and use of inoculants for silage. FEMS Microbiol. Rev., 19(1): 53-68.

Wu, J.J.; Du, R.P.; Gao, M.; Sui, Y.Q.; Xiu, L. \& Wang, X. (2014). Naturally occurring lactic acid bacteria isolated from tomatopomace silage. Asian-Aust. J. Anim. Sci., .27(5): 648-657 